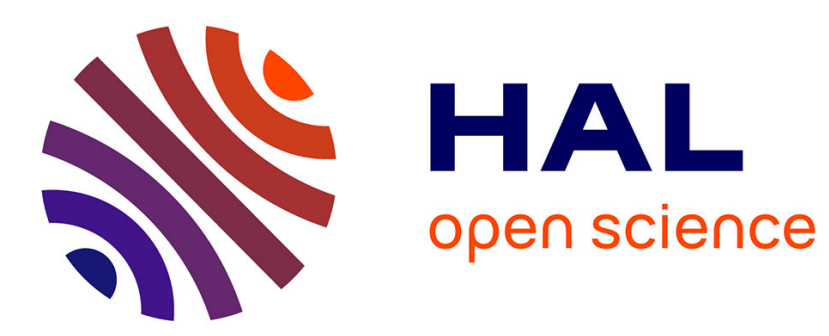

\title{
How to Improve the Capture of Urban Goods Movement Data?
}

\author{
Danièle Patier, Jean-Louis Routhier
}

\section{To cite this version:}

Danièle Patier, Jean-Louis Routhier. How to Improve the Capture of Urban Goods Movement Data?. BONNEL P., MADRE J.-L., LEE-GOSSELIN M., ZMUD J (Eds). 8th International conference on Survey Methods in Transport, may 2008, Annecy (France), 2008, Annecy, France. halshs-00328991

\section{HAL Id: halshs-00328991 https://shs.hal.science/halshs-00328991}

Submitted on 10 Oct 2008

HAL is a multi-disciplinary open access archive for the deposit and dissemination of scientific research documents, whether they are published or not. The documents may come from teaching and research institutions in France or abroad, or from public or private research centers.
L'archive ouverte pluridisciplinaire HAL, est destinée au dépôt et à la diffusion de documents scientifiques de niveau recherche, publiés ou non, émanant des établissements d'enseignement et de recherche français ou étrangers, des laboratoires publics ou privés. 
Reference paper presented at the Session: "Urban goods surveys" $8^{\text {th }}$ International conference on Survey Methods in Transport, Annecy (F), may 2008

\section{HOW TO IMPROVE THE CAPTURE OF URBAN GOODS MOVEMENT DATA?}

Daniele Patier, Jean-Louis Routhier, LET, Université de Lyon, France

\section{WHY URBAN GOODS MOVEMENT SURVEYS TODAY?}

The surveys specifically focused on the thorough knowledge of urban freight transport appeared about ten years ago. There are many reasons for that. The main reason is that the issues and requirements encountered by the urban authorities have changed recently. In fact, for a long time, the aim has been to develop transport infrastructures because of the requirements of the economic growth, in areas with not much traffic congestion. Thus, efforts were essentially focused on long haul transport. The local problematic of goods transport at local level was partially taken into account by the city planners and by the researchers: until recent years, the integration of goods transport in the total urban flows models was estimated applying a multiplying factor to car traffic. Delivering goods was not considered like a concern.

Because of the quick growth of car traffic in the cities, the main stakes changed too: the fight against traffic congestion, the management of the lack of space (shipment consolidation and storage), the attempts to reduce local environmental impacts and global externalities (energy saving, reduction of greenhouse gas emissions), and economic valuation of city centres (under the pressure of a slowed down economic growth).

All these changes were taking place in a context in which available rooms for manoeuvre were limited by factors such as congestion, concerns about the quality of urban life and budget restriction. It resulted in a growing unease on the freight transport industry and the city 


\section{$28^{\text {th }}$ International conference on Survey Methods in Transport}

authorities, the latter having little or no data, methods and references in order to elaborate a satisfactory policy framework.

The urban goods transport has specific characteristics linked to:

- products: numerous contributors, influence of upstream firm logistics, quick changing in logistics management (decease in parcels size, downstream orders...)

- urban logistics: hegemony of road transport, large diversity of delivery vehicle's lines (from two wheels vehicles to 44 tons trucks), different organisations (rounds, direct trips), large part of own account transport, lack of foresight of actors (subcontracting, possible moonlighting), expansive last mile movement, congestion, strong constraints in road sharing, intervention of local authorities for regulation and planning.

Theses specific characteristics require to take into account the urban goods transport as a specific field of research: urban logistics.

Such a field is not yet very investigated, so there is no consensus on the urban goods transport definition. That is why it is necessary to precise what is taken into account in urban goods movement.

The figure 1 shows the global field of urban goods transport.

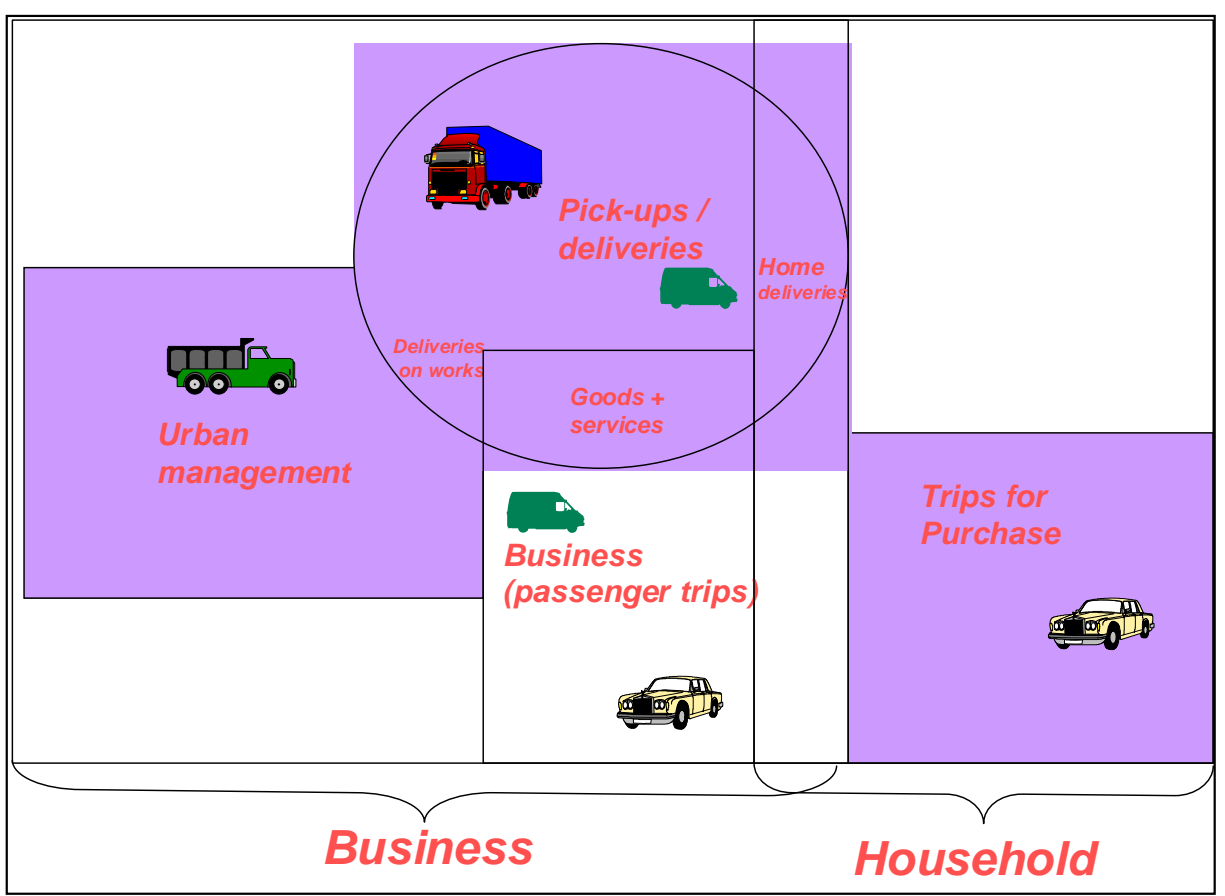

Figure 1: The components of urban goods and business traffic

All vehicles which carry goods are involved:

- Delivery vehicles used for inter-establishments trade (commercial, industrial, services), for delivery to home, to works,

- Vehicles for business trips (craftsmen who carry goods from depot to site for example),

- Own account and professional transport, 
- From 2 wheels vehicles to articulated lorry,

- Particular vehicles which carry goods (household purchasing),

- Vehicles involved in the urban management (waste, postal service, removal, hospital, public works, building works)

The grey patterns proceed of urban goods traffic. It is essential to take these three parts in order to take into account the whole urban logistics problematic.

The current meaning of urban goods transport is related to pick-ups and deliveries carried out in own account or third party. It includes goods and materials for works, home deliveries and goods movement associated with business services.

Trips for purchasing have to be integrated in surveys about urban goods transport in so far as the household carry goods in their car. Their contribution is more than half of vehicle*km car unit of road occupancy compared to all components of urban goods transport (Patier, Routhier 1998). They cannot be investigated in the same survey with inter-establishment trade. Specific household transport surveys take place about every 10 years. It is nevertheless not so easy to have an unbiased estimation of the origin-destination trips for purchase with those surveys (Routhier J.L., Segalou E. et all. 2001).

Specific surveys are necessary for urban management. Building and publics works take place in various areas and from time to time. The postal distribution concerns both establishments and households. It is impossible to take into account the global traffic it generates in such surveys. The postal office is able to give roughly how many vehicles (and what type of them) are running in the city and how many kilometres are travelled. The data may be included in the global results. The same thing goes for waste collection.

Business traffic consists in goods transport realised by heavy trucks (more than 3.5 tonnes) and business trips realised by light vehicles ( $<3.5$ tonnes) concern more personal trips (household survey) than goods movement; for example trips realised for commercial function without any goods movement. About one third to half of business passenger traffic are counted in the framework of the household surveys! in fact, the borders are vague between goods, professional and individual trips. All in or outbound goods, and moving inside the city are concerned.

This paper will focus on the core of urban goods movement data collection (see the movements generated by the activities inside the circle of the figure 1), that is the freight transported for deliveries and pick-ups, including home deliveries, delivering works (e.g. construction) and simultaneous business and goods supplying (e.g. a photocopy repair company delivering and installing spare parts). The following state of the art presents a non exhaustive but illustrative review of the diversity of the survey methods and case studies lately carried out. It is based, notably, on the work of the Bestufs II European project (Bestufs.net) and on our own experience of surveys in France. 
$48^{\text {th }}$ International conference on Survey Methods in Transport

\section{StATE OF THE ART}

Reviews of freight data collection have taken place in a few of the countries surveyed, as well as in other countries outside the EU. Such reviews are typically used to establish what data has being collected, why and how it is collected, and the extent to which the data being collected meets the data requirements in terms of factors such as supporting freight policy decision-making and freight modelling. However, where such reviews have taken place, they tend to be concerned with freight data at a national level, rather than specifically at an urban level.

\section{The Reviews}

In France, a review carried out by LET on behalf of the French Ministry of Transport in 1994 concluded that there was a major lack of urban freight data collection. More recently, a comparison of the objectives, methods and results of urban goods movement in nine industrialised countries of Europe, America and Asia was presented in Ambrosini C. and Routhier J.L., (2004). This review shows a similarity of objectives, but different approaches in data collection methods and models. It highlights the lack of comprehensive surveys on urban goods movement and the need to take account of urban logistics in the broadest sense.

In Germany, an inventory of all data collected that concerned commercial traffic was carried out between 1997-2000 by a special research team on behalf of the German Ministry of Transport. The objective was to review the available data on commercial traffic, to identify possible extensions to existing data collections and also to produce recommendations to overcome possible deficits in the existing data collected.

In the UK, the Department for Transport commissioned "The Review of Freight Modelling Project” which took place between 2001 and 2003. This project considered data requirements and data sources currently available in UK for freight modelling purposes (WSP, et al., 2002). Much of the review was at the national and regional scales, but urban scale was considered. Work by the University of Westminster for Transport for London (TfL) has reviewed freight data sources for London (reference to be provided by University of Westminster).

Garrido R. (2001), Wermuth et al. (2004) pointed out that there was a lack of in depth studies for freight and commercial transport survey methodology. They make some recommendations for future international conferences ISTCR in critical analysis of the whole of current surveys. Wermuth et al. (2004) made a thorough review of business traffic surveys in Germany. 
The BESTUFS I project has also previously examined urban freight data in 17 selected European countries, in terms of the availability of such data (BESTUFS, 2000, 2003). In BESTUFS II (2004-2008) Coordination Action, Browne M. \& Allen J., (2006) edited a review of Urban Goods data collection in 11 European countries .

In the USA, a review was carried out by the US Transportation Research Board (TRB) into national freight data in 2003 (TRB, 2003).

OECD report on urban freight transport in 2003 (OECD, 2003). is fully devoted to the topic of urban goods delivery in urban areas. It notes the lack of data and analytical tools for evaluating effectiveness of urban distribution policy measures. It suggests there is a need for standardisation of data to understand and monitor urban freight transport to improve comparability and consistency.

Eurostat (2006) about road freight data is typically published at a national level but contains some data about urban freight transport activity within it.

\section{Urban freight oriented projects confronted with data collection issues}

Numerous European network initiatives devote themselves to harmonise the different approaches of urban goods movement data collection:

The EU Cost 355 WATCH (Changing behaviour towards a more sustainable transport system, 2004-2008) includes the "Freight transport and energy consumption” work group 1. Data collected aimed at the calculation of the fuel consumption and $\mathrm{CO}_{2}$ emissions of the goods transport all along the chain from the source to the consumer (collection of raw material, processing, consolidation, wholesale and retail sale by the household). A rich assessment was carried out at a very detailed level (textile, fresh dairy produces) and about various last kilometres impact calculation. It has been shown that it is possible to know the energy consumption in the different links of the supply chain. The main issues have been the last mile, the main indicators of change, which data collection to assess those indicators and above all, does data exist?

EU project City Freight (2006-2009) undertakes a comparative analysis of the effects of the main efforts for different cities and situations in Europe. The socio-economic and environmental impacts of changes in freight transport and door-to-door delivery in a variety of European conurbation is analysed in a systematic and innovative way. In order to do that, City Freight will carry out an analysis of some selected supply chains schemes that are already functioning in Europe and carry out an evaluation of their impacts in an urban context, making use of a common assessment methodology. 


\section{$68^{\text {th }}$ International conference on Survey Methods in Transport}

The EU project START (“Short term Actions to Reorganise Transport of Goods, 2006-2009) is developed in the frame of the Intelligent Energy Europe Programme. Its aim is to turn consolidation of deliveries, access restrictions and incentives towards sustainable development in five European cities. ... what are the data issues?

Three EU Interreg III B projects under the leadership of Regione Emilia Romagna (It.) have a link with surveying goods transport in urban areas:

- City Ports is a Interreg III-CADSES project The main features of CityPort methodology concern the systematic analysis of the supply chains behind the haulage of goods, a careful identification of the most critical conditions within the cities, the identification of specific solutions according to an integrated approach, comprehensive ex-ante evaluation and attention paid to all stakeholders interested by the policy measures. This approach needed a large collection of data through surveys in several Italian middle sized cities

- Mataari is a Interreg III-MEDDOC project for the improvement of the accessibility of the transport facilities in the urban centres (consolidation centres) and the inter-modal platforms. The aim is to reduce the conflicts between the various components of the traffic and to promote the inter-modal freight transport.

- Merope is also a Interreg III MEDDOC project who is interested in the telematics oriented to logistic management in the urban and metropolitan areas. It was the occasion to make a review of the different applications of the new ICT in the frame of the urban logistics.

Citylogistics biennial conferences, driven by Pr. E. Taniguchi from Kyoto University, favour the development of a world-wide academic network on urban freight transport analysis. A lot of papers about case studies, modelling aspects of city logistics are presented and refer often to data collection gaps. We found therefore no notable reference to thorough innovative UGM surveys.

\section{Bestufs II : a recent survey on urban goods data collection}

- In Bestufs II, the Laboratoire d'Economie des Transports (Lyon) is leading a work package entitled "Urban freight data collection harmonisation and modelling”. Through a questionnaire delivered to 70 European experts (35 respondents) in 11 European countries, it was made possible to compare urban freight data collected on a national basis. The work consisted in linking the urban data collected in each country with the objectives of the collection, the methodology used, the frequency, the unit observed, sample size and many others item described below. 


\begin{tabular}{|c|c|c|c|}
\hline Type of data collection : & Countries & level & Concerns: \\
\hline Commodity flows (O/D) & $\begin{array}{l}\text { Belgium, Sweden, } \\
\text { Switzerland }\end{array}$ & $\mathrm{N}$ & $\begin{array}{l}\text { Exchanges between regional } \\
\text { areas }\end{array}$ \\
\hline Site/Land Use/Establishment surveys & $\begin{array}{l}\text { Belgium, Germany, } \\
\text { France, UK } \\
\text { Netherlands }\end{array}$ & $\begin{array}{l}\mathrm{N} \\
\mathrm{SUS} \\
\mathrm{RS} \\
\end{array}$ & Movement generation \\
\hline $\begin{array}{l}\text { Goods vehicle activity surveys (including driver } \\
\text { diary surveys) }\end{array}$ & $\begin{array}{l}\text { All countries (9), except } \\
\text { Hungary, Netherlands }\end{array}$ & $\begin{array}{l}\mathrm{N} \\
\text { SUS }\end{array}$ & $\begin{array}{l}\text { Vehicles use and } \\
\text { traffic }\end{array}$ \\
\hline Shipper surveys & $\begin{array}{l}\text { France, Switzerland } \\
\text { Belgium } \\
\text { Germany, Spain } \\
\text { Italy }\end{array}$ & \begin{tabular}{|l|}
$\mathrm{N}$ \\
OUS \\
SUS \\
$\mathrm{CD}$
\end{tabular} & All sending \\
\hline Receiver surveys & $\begin{array}{l}\text { Be, Fr, Ge, It, Neth, Sp, UK } \\
\text { Switzerland }\end{array}$ & $\begin{array}{l}\text { SUS } \\
\mathrm{N}\end{array}$ & All deliveries \\
\hline Good vehicle fleet licensing data & $\begin{array}{l}\text { All, } \\
\text { Except Hungary } \\
\text { SPAIN } \\
\end{array}$ & $\begin{array}{l}\mathrm{N} \\
\mathrm{SUS} \\
\mathrm{RS} \\
\end{array}$ & All vehicles \\
\hline Traffic counts & $\begin{array}{l}\text { Ge, Portugal, Sweden } \\
\text { Be, Fr, Uk } \\
\text { Hun, It, Neth, Sp, Sw, }\end{array}$ & $\begin{array}{l}\mathrm{N} \\
\text { AUS } \\
\text { SUS } \\
\end{array}$ & All vehicles \\
\hline Distribution industry surveys & Ge, It, Neth, UK & CD & Logistics chain \\
\hline Vehicle operating cost surveys & $\begin{array}{l}\text { Be, Fr, It, } \\
\text { Ge, Neth, Switz } \\
\text { Sp }\end{array}$ & $\begin{array}{l}\mathrm{N} \\
\mathrm{CD} \\
\mathrm{R} \\
\end{array}$ & Cost \\
\hline $\begin{array}{l}\text { Loading/unloading/parking infrastructure data for } \\
\text { goods vehicles }\end{array}$ & $\begin{array}{l}\text { Be, Hungary, } \\
\text { Fr, Port, Sp, } \\
\text { Neth } \\
\end{array}$ & $\begin{array}{l}\text { OUS } \\
\text { SUS } \\
\text { AUS } \\
\end{array}$ & Way of deliver \\
\hline Data on road accidents involving goods vehicles & $\begin{array}{l}\text { All, except } \\
\mathrm{Hu}, \mathrm{Sp}\end{array}$ & $\begin{array}{l}\mathrm{N} \\
\text { OUS } \\
\end{array}$ & Security \\
\hline Data on lorry/lorry load thefts & $\begin{array}{l}\text { Be, Fr, Neth, UK } \\
\text { Ge, Switz }\end{array}$ & $\begin{array}{l}\mathrm{N} \\
\mathrm{CD}\end{array}$ & Security \\
\hline $\begin{array}{l}\text { Employment surveys in freight transport and } \\
\text { logistics industry }\end{array}$ & $\begin{array}{l}\text { All, } \\
\text { Except Hun, Sweden, Switz }\end{array}$ & $\begin{array}{l}\mathrm{N} \\
?\end{array}$ & Employment \\
\hline $\begin{array}{l}\text { Land use databases for town/city needed for freight } \\
\text { modeling }\end{array}$ & $\begin{array}{l}\text { Fr, Ge, UK } \\
\text { It } \\
\text { Portugal }\end{array}$ & $\begin{array}{l}\mathrm{N} \\
\text { OUS } \\
\text { SUS }\end{array}$ & $\begin{array}{l}\text { Location, } \\
\text { Road occupancy }\end{array}$ \\
\hline Port freight traffic data in the urban area & $\begin{array}{l}\text { Neth, UK } \\
\text { Be } \\
\text { Fr, Ge, }\end{array}$ & $\begin{array}{l}\mathrm{N} \\
\text { OUS } \\
\mathrm{CD} \\
\end{array}$ & Contribution of port to UGM \\
\hline Rail freight traffic data in the urban area & $\begin{array}{l}\text { UK } \\
\text { Neth } \\
\text { Ge } \\
\end{array}$ & $\begin{array}{l}\mathrm{N} \\
\text { OUS } \\
\mathrm{CD} \\
\end{array}$ & Modal Share of UGM \\
\hline $\begin{array}{l}\text { Inland waterway freight traffic data in the urban } \\
\text { area }\end{array}$ & $\begin{array}{l}\text { UK, Neth, } \\
\text { Fr, Ge }\end{array}$ & $\begin{array}{l}\mathrm{N} \\
\mathrm{CD}\end{array}$ & Modal Share of UGM \\
\hline Airport freight traffic data in the urban area & $\begin{array}{l}\text { Be, Fr, Ge, } \\
\text { UK, Neth }\end{array}$ & $\begin{array}{l}\text { CD } \\
\text { NS }\end{array}$ & \begin{tabular}{|l} 
Contribution of airport to \\
UGM
\end{tabular} \\
\hline $\begin{array}{l}\text { Freight “NTIC" data (from cameras, sensors \& } \\
\text { other automatic data capture devices) }\end{array}$ & Neth, UK & $\mathrm{CD}$ & $\begin{array}{l}\text { Movements of vehicles, } \\
\text { traffic }\end{array}$ \\
\hline
\end{tabular}

\begin{tabular}{|c|c|c|}
\hline $\begin{array}{l}\text { Key to Table: } \\
\text { ? - uncertainty exists about whether freight } \\
\text { data is collected }\end{array}$ & $\begin{array}{l}\text { NS = national survey/data collection, SUS = } \\
\text { survey in some urban areas } \\
\text { RS = regional survey/data collection, OUS = } \\
\text { survey in one urban area }\end{array}$ & $\begin{array}{l}\text { AUS = survey in all urban areas } \\
\mathrm{CD}=\text { data collected by companies, trade } \\
\text { associations or other commercial organisation }\end{array}$ \\
\hline
\end{tabular}

Table 1: inventory of urban goods data collection in European countries 


\section{$88^{\text {th }}$ International conference on Survey Methods in Transport}

The freight experts surveyed were asked about the availability of the following categories of urban freight data in their country:

- Name of data collection survey

- Observation unit (vehicle, commodity, establishment, depot, delivery/pick-up,...)

- Name of organisation collecting data

- Reason for data collection

- Whether the data used for modelling

- Frequency of data collection

- Last time data was collected

- Type of data collected

- Method of data collection

- Sample size

- Units of measurement used

- Geographical area over which data collected

- Difficulty involved in extracting urban data (if data set is greater than urban)

The diversity of the responses highlight the need to harmonise definitions and units of observation if we are to expect to be able to compare the outcomes in relation to the survey's objectives. In some surveyed countries such as Hungary and Portugal_there have been few efforts to collect urban freight data in the past ten years. However, this situation is expected to be improved in Portugal over the next five years as a result of increasing congestion and concern about environmental problems (Browne M. et al. 2007).

\section{Freight data is collected for a wide range of reasons}

- Investigating specific projects and initiatives,

- To produce national and local estimates,

- Government monitoring and performance measurement,

- For freight transport modelling and forecasting (to improve its efficiency and reduce its negative impacts),

- To meet requirements of EC Directives,

- Commercial monitoring (i.e. company vehicle operating and marketing data),

- Helping the regulation setting up.

- Legal requirement for licensing and safety controls,

- Crime investigation (e.g. speeding and loading offences),

Maybe need to say that the variety of motives for collection also make for diverse surveys that can be very difficult to compare between different countries. Urban freight data may be collected according to different methodologies. 


\section{Methodologies and approaches in freight data collection are diverse}

The information provided by freight data experts has indicated the breadth of different techniques that are currently being used to collect urban freight data. These techniques include:

- Interviews with freight transport company manager

- Interviews with establishment manager (receivers/shippers)

- On consolidation platforms or roadside interviews with drivers

- Questionnaires sent to freight transport company managers

- Questionnaires sent to drivers

- Questionnaires sent to receivers

- Questionnaires sent to shippers

- Accompanied trips with goods vehicle drivers

- Group discussions (including discussions with drivers, representatives from a single supply chain, representatives from different supply chains)

- Parking and loading activity surveys (i.e. observation surveys)

- Parking and loading infrastructure/inventory surveys

- Traffic counts (manual and automatic)

- Data collection using new technology including use of satellite tracking data containing goods vehicle activity (GPS), of roadside camera data (including automated number plate recognition (ANPR) data), of weigh-in-motion (WIM) technology to measure axle weight of a moving vehicle.

Obviously the technique used to collect data can be influenced by the type of data that is being collected and the use to which it is being put (for instance data used to provide a quick snap-shot of an existing situation is likely to be collected using a different methodology and sampling approach to data used as an input to a freight model).

\section{Addressing gaps in urban freight data collection}

A wide range of urban freight data gaps have been identified by the freight experts participating in this study (Bestufs II / Browne \& Allan 2006). The most commonly mentioned data gaps include:

- data about light goods vehicle activity (generally vehicles below 3.5 tonnes gross vehicle weight)

- data about the supply chain as a whole

- data about freight and logistics infrastructure to and from which urban freight activity takes place

- data about loading and unloading operations and infrastructure for goods vehicles

- geographical data about goods vehicle trips in urban areas 
- data about trips carried out by consumers for the purposes of shopping

- speed and route data for goods vehicles

- data for non-road modes

European countries where specific large urban freight surveys were collected are seldom. It was carried out mostly in Germany, Italy and France. In most case, there are only national surveys, because of the lack of appreciation of the need for urban freight data by national, regional and urban governments.

\section{Common surveys}

This review shows that the regular national approaches are often similar and are not specifically urban oriented. We present nevertheless their positive and negative aspects, relating to urban freight objectives.

\section{Automatic counting (magnetic loops)}

In all the European countries, traffic data are usually collected by means of traffic counts. The device is either a double cable either a magnetic loop buried under the pavement. It permits to know the number of heavy vehicles (more than two axles) and cars using a road in different periods (day, week, ...). It is useful for monitoring and provision of traffic, for validating the results of specific surveys, for calibrating models for traffic generation and O/D matrices. It is used by the authority in charge of the road; it is easy and not expensive.

Road-side surveys (or “cordon” surveys).

Those surveys consist in stopping the vehicles on the roads and interviewing the drivers about their trip, the origin and the destination, the different stops and purpose. They permit to calculate the number of different types of vehicles using the road, and, when they are made around an area, to have the through traffic and the exchange traffic of the area. Only few questions are put (for acceptability). It is not possible to link the industry activity with the purpose of the trip or the freight carried. Internal traffic in the areas is not calculable. It permits to validate and calibrate the results of specific surveys and models. The management of those surveys is not easy: it causes often traffic jams and concerns of road safety, so a number of truckers were determined to avoid the survey sites. Some truckers take alternate routes to avoid the survey locations (in France, for those reasons, such surveys have been given up these 15 last years). 


\section{Vehicle based surveys}

The most current surveys consist in picking a sample in the vehicle registers. In France, like in a lot of developed countries, they are carried out by national authorities, they are also named national LGV and HGV surveys.

\section{The freight road transport business vehicles surveys}

Those surveys are carried out yearly by the national French statistical authority (SESP). They conform to the European standard CE 1172/98. A questionnaire is sent all along the year to the owners (or for hire user) of more than 3.5 tons vehicles. The respondent fills a log about the transport realised with the vehicle in a day during the last week. The results are updated on a annual basis, thanks to a quarterly picking of a representative sample on the national heavy vehicles register. They permit to evaluate the traffic performance of large goods vehicles and each year, the tons and types of goods (according to 12 Transport Statistical Nomenclature NST) and vehicles sent on road from a region to another. It is the main way for calibration of the inter-urban freight traffic models (commodity flow models). In France, 15,000 rigid trucks and 70,000 articulated vehicles are surveyed each year.. The survey is general interest and compulsory. The short trips $(<50 \mathrm{~km})$ travelled in the dense areas and those including several stops are generally not surveyed.

\section{Periodic surveys on light commercial vehicles.}

Few countries carry out periodic surveys on light commercial vehicles (LGV). In France, SESP carries out every 5 years a national survey on the use of the LGV ( $<3.5$ tons). A representative sample of 20,000 vehicles is picked on the national light commercial vehicles register. Each owner receives a postal questionnaire and gives informations on the average yearly use of the vehicle (part of individual or occupational use, part of urban or interurban use, part of goods, tools, material, individual transport). They permit to evaluate the traffic performance of light goods vehicles, to evaluate periodically the tons and types of goods (according to 12 NST) sent by the trucks from a region to another. The survey is compulsory for the occupational users. Since 2000, a diary log, on two days, was added, that makes possible having a more accurate description of the spatial and occupational use of the vehicles. Nevertheless, with this addition, the postal survey method reaches a threshold: the response rates are decreasing with a higher complexity of the questionnaire.

\section{Vehicle based surveys}

KID 2002 survey in Germany is an example of global vehicle based survey at national and regional levels (Wermuth M. et al., 2004). At the federal level, a representative selected 


\section{$128^{\text {th }}$ International conference on Survey Methods in Transport}

sample of 100,729 vehicles was picked among the vehicle population on 2001, giving a net sample of 51,778 vehicles. 25,019 net cases of the regional surveys were added to the total federal survey. According to goods transport, 4,249 commercial owners of cars and commercial and private owners of lorries up to 3.5 tons, 1,131 owners of semi-trailers and lorries $>3.5$ tons have been included. Stratification of goods vehicles was vehicle based (type and age of vehicle), owner based (private and commercial use, 17 types of activity) and spatial (4 urban types, 3 urbanised areas, 2 rural areas) for representative sampling. A minimum of 240 vehicles per stratum was provided. The survey documents include a questionnaire on vehicle and owner, a travel diary on reference day (gross weight of load, type of goods, address and kind of destination, end of trip and distance travelled. The KID 2002 survey greatly improved the information base available for German traffic statistics. It was possible to have an estimation of the amount of the private, business and commercial traffic all overall Germany, including the annual performance of each vehicle groups ( number of trips and number of kilometres). Indicators are calculable: percentage of mobile vehicles, traffic involvement per mobile vehicle, goods transport performance per mobile vehicle (tkm/veh/day) and trip related characteristics as mean volume goods transported per load trip (kg). To our knowledge, local and urban data have not been calculated. Stops are not described precisely and it is not possible to have a thorough picture of the route, weight and type of goods transported. Those surveys do not describe the variety of the flows generated in the urban areas. That is the reason why, despite the additional questions, extensive surveys are requisite.

\section{Shipper surveys}

Two main shipper surveys have been carried out by INRETS (The French National Institute for Transport and Safety Research). The « Shipper » survey took place in 1988 and « Echo », (Envois, CHargeurs-Opérateurs de transport)» was conducted in 2006. A test survey has been conducted in 2003 (Rizet C. et al. 2004). The main feature is to track the shipments all along the transport chain, from the shipper to the consumer. Supply and demand of goods are observed through the follow of the sendings carried out by the shippers. The aim is to identify the logistic determinants of the transport chain in order to analyse the behaviour of the involved parties in the transport chain. Information was collected directly to the shippers, carriers, customers and also the forwarders or logistic services providers concerned.

A representative sample of 2,935 establishments was picked among 78,000 (industry, wholesale, mail-order companies with more than 10 employees). 9,742 dispatch among 10,462 have been tracked from the shippers to the final destination. The establishment sample was stratified according to the activity and the employment. For each of them, the 20 last dispatch have been surveyed. The less used modes (sea, air, train, containers road-rail, river) 
and the international dispatch have been over-represented, in order to ensure a good description of them. Five consecutive questionnaires have been submitted: a postal establishment questionnaire for transport activity; an interview with a relevant person of the same establishment (economical characteristics and relation with partners as carriers, customers, forwarders or logistic services providers); a dispatch questionnaire (relationship between shipper and customer, organisational and physical characteristics of the dispatch; phone interview (follow up the dispatch, with the role price and the purposes of the modal choice of each operator in the chain); trip questionnaires, completed by the carriers, (breakdown of the dispatch if several vehicles are needed, different stops, processing of the goods, description of the route).

Those surveys permit many researches on freight demand analysis and modelling: traffic generation, spatial distribution, transport organisation, sub-contracting etc. A logit modal choice model enables to estimate the modal split for each segment and to predict the new split in the case of demand changes. It is already possible to analyse the evolution of the transport chains between 1988 and 2005. It is possible to compare the shipments in different sizes of urban areas (Dufour J.G., 1995, Beaudoux 2006). However, it is not possible to consider the last miles travelled in rounds, the dispatch from the retailers are not considered. Weightings are made for the expansion of the sample to the whole country, but it is not fitted for the different urban areas. It is not easy to use the results of those surveys at urban level.

\section{Conclusion}

Among the more or less common approaches described above, none of them was designed to answer the global specificity of the urban freight transport. Apart KID survey, which takes every type of vehicle into account, other surveys consider only one type of vehicle or. describe the start point of the transport chain of the sending (Shipper surveys). For those reasons, the observation units used in those surveys (vehicles, shippers) do not allow an exhaustive description of the variety of the urban goods transport flows. Those current approaches have to be compared with some more recent approaches, establishment-based surveys and tour-based surveys.

\section{An evolution of the methods}

We present the approaches who appear, in our opinion, the most efficient for urban specificity and promising to answering the specific urban issues. 


\section{$148^{\text {th }}$ International conference on Survey Methods in Transport}

\section{Business and vehicle travel regional surveys in Hamburg and Dresden.}

In both regions of Hamburg and Dresden, a business survey with a vehicle travel diary survey have been carried out in the 2000'. (Steinmeyer, 2003). Those surveys give a good description of the whole business traffic generated in relation with their different types of urban purpose. In Hamburg, it was mail-out and face to face interviews, in Dresden only face to face interviews. An establishment survey collected the characteristics of the business, the owned or hired vehicles and employment. Then, for each commercial vehicle a travel diary was filled in order to survey the travel of the employees in commercial vehicles. In Hamburg, among the businesses contacted by post and phone, the response rate of mail-out was 36\%, 40\% for the interviews. This rate was $42 \%$ in Dresden. The response rate in the vehicle diary survey is about $30 \%$. The results permit the counting of the own account and for hire vehicles movements generated by different activities. Because only the owned commercial vehicles were surveyed, it is not possible to calculate the ratios of deliveries and pick-ups in a given establishment. Furthermore, it appears that the organisation of the various types of operations seems difficult to be assessed (round or direct trip, sizes of rounds, activity of the business delivered or removed...). Such surveys are not specially oriented to the logistician behaviour analysis and to assessment of the impact of the business activity on urban freight traffic.

\section{One shot surveys about $L G V$}

In the last past years, significant surveys were addressed to the analysis of deliveries with light vehicles. In the Ile de France (Region of Paris), a survey was carried out by IAURIF (Institut d’Aménagement et d’Urbanisme de la Région Ile de France), concerning the use of the LGV. The goal was to enlighten the extend and the use of LGV in order to complete the results of the TRM survey (see above). Between 2000 and 2002, one survey was carried out on the delivery place towards the drivers; a consignee establishment survey was also addressed; another survey was carried out in the loading places. In total, 2,950 drivers, 3,240 establishments were surveyed. The consignees had to describe their receipt in the form of frequency of delivery with LGV and HGV per day, week and month, with the share of products for sale, material and components, other providing. Duration of stocking, time and conditions of deliveries have been noted. The driver survey described the current loading or unloading operation, with a description of the three next delivered places. On board devices and traffic conditions were also noted down. The sampling of the establishments was made in order to focus on specific streets and the characteristics of the establishment (size, accurate activity) have not been noted. It was so impossible to make a sample expansion to the whole urban area. It was essentially used to have a picture of various behaviours of delivering goods with LGV in the Paris area. 


\section{A survey in The Netherlands}

In order to uncover the relationship between firm characteristics and freight traffic, Iding M., Meester W.J. et al. (2002) built a model generation based on firm-level survey data from a heterogeneous population. A large-scale survey was carried out in The Netherlands. Postal interviews have been sent to an initial sample of 10,000 firms (at least 5 employees), selected on the type of activity and size. The questionnaire was quite short, with questions on core business, site and floor area, number of employees; average number of trucks per day bringing and taking out freight per type of vehicle, transport mode, loading units and organisation of transport were made clear. The target response rate was about $15 \%$. A regression analysis of bringing in and taking out trucks was made for each sector of industry, according two variables, site area of the firm (m2) and the number of employees. The survey brings a good knowledge on the traffic per branch. The effect of the number of employees on bringing in freight vehicles is often different from its effect on the taking off vehicles in several sectors. Regional differences for the freight traffic indicators are not significant. We notice that the survey was not exhaustive: the small establishments (less than 5 employees) are missing, (while the French surveys showed that the less than 5 employees about $50 \%$ of the total deliveries and pick-ups in the French urban areas).

\section{CityPorts : The initiative of Emilia Romagna}

CityPorts (EU INTERREG III/B 2003-05), co-ordinated by Emilia-Romagna Region (It), proposed a general methodological framework for the design and evaluation of City Logistics Actions (Gentile, Vigo, 2007). The collection method lead to analyse the different supply chains and their impact on the different zones of the urban area. For each zone, the main supply-chains (SC) are defined on the basis of a stratification of the various industries operating in the zone. A survey have been carried out in several cities of Emilia-Romagna in order to assess the generation of urban freight transport (operations) and to obtain the distribution of different attributes on demand generation, attraction and flows per operations per SC. The sampling of establishments has been based on the ATECO (only large companies) economic classification and the number of employees. The questionnaires included questions on operations generated, parking type, time of service, timetables, type of vehicle,...).

In each city, the size of the samples was 250 to 500 establishments. According to the authors, the methodological approach was inspired from the French survey methodology. It is thus easy to compare the results of the Italian and French surveys: the breakdown of parking duration are quite similar (mode is about 5 minutes), peak hour is between $10 \mathrm{~h}$ and $11 \mathrm{~h}$. 
Parking types are different and service days are more regular in France. From this data collection it was possible to develop a logistic demand generation model (Gentile, 2006).

\begin{tabular}{|l|l|}
\hline \multicolumn{1}{|c|}{ Surveys of: } & \multicolumn{1}{c|}{ Description } \\
\hline $\begin{array}{l}\text { Flow generators } \\
\text { (establishments) }\end{array}$ & $\begin{array}{l}\text {-Private information and supply chains characteristics } \\
\text {-Comments on city logistics situation and perspectives } \\
\text {-Information about loading and unloading }\end{array}$ \\
\hline $\begin{array}{l}\text { Operators : Local } \\
\text { transport } \\
\text { companies }\end{array}$ & $\begin{array}{l}\text {-Private data and "static” information about the supply chains, fleet and } \\
\text { infrastructure } \\
\text {-“Dynamic” information on transport weekly activities }\end{array}$ \\
\hline Hauliers & $\begin{array}{l}\text {-Vehicle and goods information and supply chains } \\
\text {-Travel information about journey and route }\end{array}$ \\
\hline $\begin{array}{l}\text { Investigation of } \\
\text { urban structure }\end{array}$ & $\begin{array}{l}\text {-Identification of homogeneous zones in terms of type of activity (distribution, } \\
\text { production) } \\
\text {-Information about urban freight traffic, urban and extra-urban road network etc. }\end{array}$ \\
\hline
\end{tabular}

\section{Table 2: description of the surveys in Cityport project}

Canadian business surveys : Edmonton and Calgary surveys

About 3,000 business establishments in the Calgary Region in 2000, 4,500 business establishments in Edmonton Region in 2001-2002 were interviewed concerning the commercial movements they generated on an assigned survey day. It was collected information on the full range of commodities being transported (any goods -physical item- or service -action performed- produced by a business establishment), together with description of vehicle movements arising with this transportation activity. An establishment based process was used, analogous to the household-based approach used in personal travel surveys. It was possible to distinguish goods and services in all the vehicle movements. (Hunt J.D; et al,.2005, Canadian Council 1999, Krüger D. 2004).

The survey objectives are the investigation of generation of goods movements, distribution patterns, influence of employment size and type on commodities shipments; investigation of vehicle movement arising with commodity movements (pattern of delivery for a given commodity flow, use of depots, all the trips needed to accommodate a commodity flow, the types of vehicles used). Three basic categories of data are collected:

\begin{tabular}{|c|c|}
\hline Questionnaires & Data collected \\
\hline $\begin{array}{l}\text { Establishment form: location, category, employment } \\
\text { and total movements of goods and services produced at } \\
\text { the establishment and leaving it by category } \\
\text { Establishment depot form: idem + the goods and } \\
\text { services entering the depot), }\end{array}$ & $\begin{array}{l}\text { Establishment data: employment of } 25 \\
\text { categories based on industrial sectors, } \\
\text { relating to the nature of production } \\
\text { process performed at establishment and } \\
\text { to the space occupied }\end{array}$ \\
\hline
\end{tabular}




\begin{tabular}{|c|c|}
\hline Questionnaires & Data collected \\
\hline $\begin{array}{l}\text { Goods shipment form: quantities values, routings and } \\
\text { final destination for goods leaving the establishment. } \\
\text { These were distributed to vehicle drivers taking goods } \\
\text { from the establishment on the collection day. } \\
\text { Goods depot form: quantities, origins, destinations, } \\
\text { vehicles used for goods entering and leaving the depot. }\end{array}$ & $\begin{array}{l}\text { Shipper behaviour data, including } \\
\text { locations of destinations for goods and } \\
\text { services on survey day, broken down } \\
\text { by size, type and value of shipments to } \\
\text { each destination. }\end{array}$ \\
\hline $\begin{array}{l}\text { Goods vehicle form: description of the pattern of all } \\
\text { stops made by the vehicle departing the establishment } \\
\text { carrying goods produced at the establishment. } \\
\text { Service vehicle form (description of the pattern of stops } \\
\text { made by vehicles carrying goods and services provided } \\
\text { from the establishment. }\end{array}$ & $\begin{array}{l}\text { Vehicle movement data: type of stops, } \\
\text { location of stops, timing of stops, size, } \\
\text { type and value of shipment exchange at } \\
\text { stops, vehicle configuration. }\end{array}$ \\
\hline
\end{tabular}

Table 3: description of the Canadian business surveys

Usually, the establishment forms were completed by the initial contact (or her designate) person, the shipment forms by the shipper at the establishment, the vehicle forms by drivers. Such a survey consists in providing information about only the shipments of production leaving the establishment. The shipments arriving at the establishment was not requested. This was adopted to avoid the "respondent burden" in order to reduce the potential amount of information to provide.

Survey process recruitment and collection: the establishment sample was developed from data supplied by Alberta Treasury, including a business name, address and industry classification. In Calgary, the lack of telephone number made necessary to spend extra time. As for the French register, a large number of duplicate and out of business establishments fond complicated the process. The recruitment of the establishments had three steps: first contact by mail, a follow-up phone call: employment of the establishment, nature of the establishment (shipping goods/services or depot), acceptance of the survey. Then, a formal letter was sent by mail or fax, and the contact person was called against in order to send the appropriate forms. The collection of data on the survey day was carried out according to three levels of assistance:

minimal: the person participating is called before and after the survey day and then the establishment is later visited in order to review the completed form.

partial: a first visit is made at the start in order to provide initial guidance as the survey got under way. A call is made after the survey day followed by a visit as above.

full: someone working for the survey firm remains on site for the entire survey day

The endorsement of the major shipper and trucking associations have been a good help. Among the 16,000 establishments initially contacted, only 3,000 completed the survey. 


\section{Sample expansion and weighting}

The individual scaling factor was determined according three variables: establishment size (nb of employees), standard industry category, geographical location. In the Edmonton Region, among 27,478 establishments contacted, 13,792 were found to shipper establishments and 4,324 completed the full survey.

Validation of the survey and results

In order to check the results of the expansion process, and potential respondent bias, the expanded set of vehicle movements were loaded to the node-and-link modelled network in the regional travel model. Assigned truck flows were found to match very closely the observed values from vehicle classification counts. Some results are not too far from the results obtained with the French urban goods surveys (share of movements, share of light vehicles): "light vehicles are used in about two-thirds of all commercial stops in a typical weekday. This is a higher proportion than is appreciated in 'conventional wisdom'. About a third of all commercial stops in a typical weekday are for service deliveries. Again, these service deliveries are often ignored in studies of freight movement or commodity flow.

The data collected has been used to develop a novel form of tour-based micro-simulation of commercial vehicle movements which has proved very successful in practice. It has been integrated with a conventional aggregate, equilibrium model of household movements, and has the potential to work with the emerging state-of-the-art tour-based / activity-based models of household travel. As such, it leads in a new direction for urban commercial movement modelling. Its development required the data obtained in this survey, and surveys of the sort described here would be required as part of developing this sort of model elsewhere. » (Hunt et al., 2005). This is a necessary but costly survey expense: in Calgary, the total amount was $\$ 600,000$ (from survey planning and design to verification and expansion), $\$ 800,000$ in Edmonton.

\section{The establishment-driver surveys in France}

A pervasive feeling of unease in France was behind the national experimental and research programme on urban goods transport, launched in 1993 by the Ministry of Transport and ADEME, the French public agency for the environment and the energy. The programme pointed out an important lack of any research in this field for about twenty years. As far as the problems of urban goods transport were concerned, neither suitable statistics were available nor systems to gather information from the various economic players involved, nor analytical method, nor methodological tools, nor monitoring of experiments. The first task was therefore to carry out comprehensive surveys in a number of different fields. There was no research body available for city authorities, and from the outset, it was quite clear that the human and 
financial resources required exceeded the capacities of any single conurbation. Moreover there was a common need for a corpus of research that could be used by anyone, not just for a specific city. The Laboratoire d'Economie des Transports has built and analysed three large original surveys between 1995 and 1997, in order to provide the quantitative elements useful for demand forecasting and vehicle flow generation in French towns. They have been carried out in the French towns Marseilles of 1,1 Million, Bordeaux of 750,000 and Dijon of 240,000 inhabitants (Patier, Routhier et al., 1997 and LET, 2000).. We call them Urban Goods Movement (UGM) surveys.

The results have notably been used as a data base for the Freturb model calibration, and as decision aid for the transport master plans of several large and medium sized French cities. In each city the same approach was carried out, based on an establishment-based survey and a tour-based (drivers) surveys.

\section{Methodology}

From our own experience, we specify the methodological precautions required to make operational urban goods movement survey. The number of vehicles located depends on the type of goods carried, their packaging, the frequency of deliveries, the type of delivery vehicles used. Required data do not exist in usual statistics (at local, regional or national levels). Generally known data are: population, employment, number of establishments with the type of their activity. In order to know the relationship between the activity and the flows of vehicles they caused, it is necessary to survey trip generators, sending or receiving goods. Only generators know precisely how many vehicles stop every day in their establishment, the size of the latter, the management of the delivery trips, the constraints of management regarding the type of goods.

We need data that is relevant for a good representation of the reality. In the urban areas, the knowledge of the freight flows is not reduced to knowing the routes of the delivery vehicles, because about $75 \%$ of pick-ups and deliveries are carried out in more or less complex rounds. It is the reason why it is advisable to re-examine the traditional four-step approach usually used in the long haul modelling (generation of the freight flows, modal shift, building of a freight and vehicle O/D matrix, assignment on the network). In order to focus the object, we can consider that the main question about goods movement is road occupancy by the goods vehicles which are in competition with individual cars. Congestion and accessibility alike local environment for residents may be translated by road occupancy.

In the standard analysis of urban mobility, the aim is to reach a good understanding of the daily individual trips. We think that we are not able to conduct a same procedure for urban goods transport as the urban public transport. An urban goods transport origin-destination matrix has no meaning in terms of transport: one tonne (or $\mathrm{m}^{3}$ ) from zone i to zone $\mathrm{j}$ can be 
carried in a single payload in direct trip between $\mathrm{i}$ and $\mathrm{j}$ as well as hundred small parcel deliveries, some of them being delivered straightforward and some other delivered in complex rounds with light goods vehicles. As the current modelling approaches are not efficient at the urban scale, that is why the underlying hypotheses do not fit.

What is the most quantifiable observation unit? In order to observe the different ways of organisation on the road of a good vehicle, several statistical units may be considered: monitoring of $a$ street segment during a defined period may provide the parking place and time and the moving of the goods vehicles working on this segment. Surveying the routes of goods vehicles provides a thorough description of the stops which make it up. Through surveying the shippers all the pick-ups and deliveries could be registered. Each of those observation units have drawbacks: the rules of sampling of street segment are difficult, the routes may not be settled into the land use characteristics, shipper surveys do not provide easily the routes characteristics.

The "movement of vehicle", in the sense of deliveries or pick-ups achieved in each establishment, was chosen as the statistical unit for the following reasons:

- A movement of vehicle may be considered through the road occupancy (as the trip and the on road parking time), that assure the measurability of the objective,

- The movements may be described through an establishment survey, in order to keyboard with a appropriate precision the useful characteristics of each movement. In particular, the space occupancy by the stationary vehicles may be precisely measured.

- In order to explain and quantify the road occupancy when a vehicle moves from the depot to the delivery zone or between two delivery points, it is necessary to complete the establishment survey with a delivery-man survey. A self managed questionnaire is filled by the drivers who have visited the surveyed establishments. By this way, it is possible to recreate the route containing the movement initially surveyed.

If the size of the sample is sufficient, such a survey may give a accurate picture of the urban goods vehicles traffic. The traffic is considered in the general sense of road occupancy for both the trips and the parking on the road. This choice also allowed us to circumvent the difficulties inherent in identifying the origin/destination flows which are one of the priority aims of the approaches usually encountered (Bonnafous, 2000).

The first major survey of this type has been launched in Bordeaux (750 000 inh.). with the active participation of the city authorities. Tracking was carried out by means of three fit together surveys:

An establishment survey was carried out from establishments shipping or receiving goods (industrial, commercial, tertiary sectors).

A driver survey concerns the driver delivering goods or picking up goods in an establishment, for own account or third party. 
A transport companies survey of the most frequently cited transport companies described: the company's activity (express, consignment, national, international, fleet, number of employees), the organisation of the transport chain, the frequency of deliveries (hourly, weekly, monthly, and annual), the fleet of vehicles allocated to deliveries in the city, trucks movements, etc., the number of pickups and deliveries, the number of rounds per day and per time period, and the type of vehicle. The organisation of the activity: location of most frequently used terminals, main logistics chains, number of rounds, number and type of vehicles involved, etc.

\section{Choice of the cities}

Carrying out a survey of this type depends on the commitment of a body responsible for managing an urban transport system. In the first survey case, Bordeaux urban Community have been involved. The choice of the perimeter of the urban area included the density of economic activity and the existence and availability of local databases. We had to set an appropriate The survey perimeter has been defined in accordance with the individual household surveys areas, in order to have available data about car and public transport road occupancy. Its corresponds approximately to the French National Institute of Statistics (INSEE) definition of the conurbation. The survey area was divided into zones similar to household trips survey zone, in order to ensure correspondence between population indicators and movements of goods. Collection method

In order to control the reproducibility of the results of the Bordeaux survey, two similar large surveys have been carried out in Marseilles (1,100,000 inh.) and Dijon (240,000 inh.) in 1996-97. The approach and the objectives were similar but the collection method has been changed. Several management modes have been carried out at each level (establishment, goods, driver, carrier) and according to the cities (Bordeaux, Dijon and Marseilles).

\section{In Bordeaux:}

Establishment survey: a questionnaire provided data through interviews of the establishment manager, on the establishment's activity, fleet of vehicles, storage possibility, parking facilities and the surrounding of the establishment. A weekly log (or diary) kept by the person responsible for logistics, provided data on all incoming and outgoing movements of goods over a week. The log consisted of a set of data sheets. Each data sheet contained informations relating to one movement in the week, including pick up or delivery data (place, time, type of vehicle, time for delivering), the carrier's name, the frequency of pick ups or deliveries and data on the product (type of product, packaging, weight, origin and destination), a removable driver-questionnaire was attached to each movement data sheet. 


\section{$228^{\text {th }}$ International conference on Survey Methods in Transport}

Driver surveys were self administered: the questionnaires were given to the drivers in the establishment where they were making a delivery/pickup and were returned by post. The questionnaire describes the round, i.e. the number of stops in the city, the type and weight class of the vehicles used, the type of handling equipment used, the distance covered and the type of each establishment delivered. The route was drawn on a map of the city and informations were given on the number, the location, the schedule and the parking time of stops.

Carriers surveys: was conducted by a transport scientist during a face to face interview.

\section{In Marseilles and Dijon:}

Establishment survey: The surveys of establishments should be realised by Computer Assisted Telephone Interviews (CATI method), to 2,000 establishments in Marseilles, 1,000 in Dijon. As the length of the interview was too long, this method was quickly replaced by a phone call and postal questionnaire.

Driver surveys: The driver survey of Bordeaux was satisfactory, but some questions were missing. In order to allow the description of the activity of the different places delivered, the description of the type, weight and packaging of the different loading and unloading, the drivers survey has been realised with a different approach: instead of giving the questionnaire to the driver when he loaded or unloaded in the establishments, the surveys took place in the company in charge of deliveries (carrier, consignee or consignor identified in the place of each establishment). For the direct trips and the simple rounds, the surveys were made by interviews of the deliverymen on the carriers or forwarders platforms or consolidation centres. In order to capture the data on the complex rounds (more than 30 delivery points) on board surveys were realised by a pollster accompanying the driver. The number of valid questionnaire was 800 in Marseilles and 500 in Dijon.

The total database of the three cities contains 4,500 establishments and 2,200 drivers questionnaires.

\section{Sampling}

The French exhaustive establishment register "SIRENE" of INSEE is easily accessible. It contains a lot of invaluable informations on each establishment, as activity, number of employees, nature of the premise etc. In the town of Bordeaux, the sample was picked from 38,507 of the 40,466 establishments of the urban area, (95\%). Public services (schools, local authorities, post offices and hospitals) were covered by separated studies and were not included in the survey. In the conurbation, these activities, which generate relatively few goods movements, account for $25 \%$ of employment, meaning that the sample covered only $75 \%$ of employment. The survey had to cover a large number of establishments in order to 
obtain acceptable results on the generation of movements in each stratum: 1,500 establishments were surveyed.

Each establishment provided five data sheets on average, concerning the same number of different movements undertaken by the same carrier in an establishment (6,600 data sheets in total). Dummy data sheets, one per establishment on average, were established for regular movements that were not carried out during the survey week. A precise description of movements during a week (nature and path of the goods of each shipment, packaging, weight) was described in 8,300 product lines. It was shown that a majority of movements are involved in a single shipment.

The sample of establishment was picked from this database. A stratified sampling method was used so as to ensure adequate representation of differing categories of establishments according to their and size with regard to the generation of movements. An a priori partition into 37 classes was build in Bordeaux, according to the industry class, the number of employees and a comprehensive geographical coverage of the conurbation.

The following table shows the 37 classes.

\begin{tabular}{|l|l|}
\hline NATURE OF THE ACTIVITY & Size of the establishment \\
\hline Agriculture & \\
\hline Craftsman of building & $>2$ employees \\
\hline Heavy Industry & \\
\hline Chemical Industry & \\
\hline Industry of producers and intermediary & $<3$ employees \\
\hline Industry of consumer goods & $>2$ employees \\
\hline Industry of consumer goods & \\
\hline Transport & \\
\hline Wholesale: intermediary producer goods & $<3$ employees \\
\hline Wholesale: non food consumer goods & $>2$ employees \\
\hline Wholesale: non food consumer goods & \\
\hline Wholesale: food consumer goods & \\
\hline Hyper market, department store & \\
\hline Supermarket & \\
\hline Mini market & \\
\hline Retailers : clothing, shoes and leather & \\
\hline Retailers : butcher's & Without employee \\
\hline Retailers : grocery, alimentation & With employees \\
\hline Retailers : grocery, alimentation & \\
\hline Bakeries and pastry shops & \\
\hline Café, hotel, restaurant & \\
\hline Chemist & \\
\hline Retailer: hardware & \\
\hline
\end{tabular}




\section{$248^{\text {th }}$ International conference on Survey Methods in Transport}

\begin{tabular}{|l|l|}
\hline NATURE OF THE ACTIVITY & Size of the establishment \\
\hline Retailer: furniture & \\
\hline Stationer's and bookseller's & Without employee \\
\hline Stationer's and bookseller's & With employees \\
\hline Other Retail trade & $<3$ employees \\
\hline Other Retail trade & $>2$ employees \\
\hline Open-air market & \\
\hline Varied Repair shops & $<3$ employees \\
\hline Varied Repair shops & $>2$ employees \\
\hline Tertiary offices & Without employee \\
\hline Tertiary offices & $1-2$ employees \\
\hline Tertiary offices & $>2$ employees \\
\hline Other Tertiary services (rental, sale) & \\
\hline Other services & \\
\hline
\end{tabular}

Table 4 : Activity stratification in the establishment survey in Bordeaux

6,000 driver questionnaires were given by the establishments taking part in the survey (903 (rate of 17\%) have been returned by the drivers, validated and linked to the surveyed establishments). 69 of most frequently used carriers have been surveyed.

A preliminary pilot study of 150 establishments was carried out in Lyons. Strategic variables were systematically monitored during the survey. Despite these precautions, numerous follow-up phone calls were needed in order to finally clear the various surveys.

\section{Expansion and weighting.}

Expansion of the sample results allows to extrapolate the observed data to the whole urban area. It consists in weighting each entity measured.

Concerning the generation of movements, the number of movements is mainly sensitive to the type of industry and the size of the establishments. The hypothesis is that the fluctuations linked to another characteristics cancel each other out when the movements are aggregated on large groups of establishment.

Weighting of establishments

This weight $w_{s}$ is specific to each strata $s$ which permitted to build the sample. It is determined by the ratio $r_{s}$ (number of establishments of the strata in the conurbation)/ (number of establishments of the same strata in the sample)

$$
w_{s}=1 / r_{s}
$$

Weighting of movements

In the dairy log, some movements were forgotten or incorrect. It was necessary to amend each weight at the establishment level in order to make possible the extension of the results from 
each data sheet of movements. It was observed that the number of movements obtained by the sum of the frequencies of movements in the data sheets were $20 \%$ lower than the actual total described by the establishment interviewed. To do the correction, the scaling factor $c_{e}$ of the characteristics of each movement of $e$ is such as:

$$
c_{e}=m_{s e} / \sum_{i_{\Perp} e} f_{i}
$$

where $m_{s e}$ is the number of movements of an establishment $e$ in the stratum $s$ during a week and $\Sigma f_{i}$ is the number of movements obtained by the sum of the frequencies $f_{i}$ of data sheet movements of the establishment $e$.

The total number of movements $M_{s}$ of vehicles generated by the establishments of the stratum $s$ is :

$$
M_{s}=\sum_{e} m_{s e^{*}} w_{s}
$$

For each stratum $s$, each movement $i$ of $e$ in the sample has a weight of $m v_{\text {sei }}$ movements in the whole study area, such as:

$$
m v_{s e i}=w_{s}^{*} c_{e} * f_{i}
$$

The hypothesis is that in each stratum, the distribution of establishments of the sample according to their number of generated movement is similar to the distribution of the establishments in the whole conurbation. In some cases, the elimination of only one establishment or its change of stratum can modify noticeably the number of movements generated by one stratum in the conurbation. It is the case of the big generators which have to be surveyed separately.

Weighting driver trips : 2 bias have been found in the driver sample :

- For each management mode, there is a distortion between the number of movements generated by the different types of activities of establishments delivered by the drivers and the number of movements generated by the whole movements slips described in the establishment sample.

- Drivers who belong to the surveyed firm answered more frequently than third party drivers: the rate of questionnaires sending back was different according to the closeness of the driver and the establishment delivered .

In order to amend those biases, the following weighting of a tour of the type $(m, a)$ was used:

$$
r \text { - }^{\text {tour }} r_{m, a}=\text { Nbmvt }_{m, a} / \text { nbmvround }_{m, a}
$$

is the weight (in weighted rounds number).

Where $a$ is the activity branch (industry, craftsman, wholesale, retail, large store, tertiary services, warehouses; agriculture) and $m$ is the management mode, in 5 classes: own account 
realised by the establishment as consignee, own account not realised by the establishment as consignee, own account realised by the establishment as forwarder, own account not realised by the establishment as forwarder, third party (carriers).

$N b m v t_{m, a}$ is the weighted number of movements calculated in the urban area for the $(m, a)$ establishments, nbmvround $_{m, a}$ is the number total of stops of the $(m, a)$ drivers trips in the driver sample.

If $n b s t o p$ is the number of stops of a round for a driver of type $(m, a)$, the weight (in number of movements) of this driver is:

$$
\text { nbmvchauf } f_{m, a}=\text { nbstop }^{*} r \text {-tour } r_{m, a}
$$

\section{Period and duration of the diary of survey}

It was all a week (Monday to Sunday), an ordinary week, without holidays. We observed that the frequency of supplying an establishment is not the day, but the week. In the city coexist so many different actors with so many different logistic organisations that it is necessary to observe all days of the week. Moreover, it is impossible to calibrate data from only one day without knowing the weight of this day in the global week. It is important to have informations on seasonally changes. It is the reason why questionnaire included questions about the weight of the surveyed week regarding the others weeks of the current month, and what is the proportion of this month in the year.

Budget: each survey needed a funding of about $500,000 €$ (in current $€$ ). It was shared between the Transport Ministry, the ADEME and the city authorities.

Main results

\section{Example in Bordeaux}

Number of deliveries and pick ups per week 270,000

Average ratio number of movements per employee

Ratio delivery - pickups

$61 \%-39 \%$

Part of own account deliveries/pickups

$56 \%$

Delivery/pickups with vehicles $<3,5$ tons

$52 \%$

Ratio of movements realised in rounds

$75 \%$

Ratio of rounds among total involved vehicles

$25 \%$

Share of retail trade (nb. of deliveries/pickups)

$33 \%$

Part of the small establishments $<5$ employees in vehicles movements : $50 \%$

Goods vehicle generation: For each branch of activity, the number of deliveries and pick-ups carried out by vans, rigid vehicles and articulated vehicles is calculable. 
Average size of the rounds is 13 delivery points, (19 in third party, 11 in consignor-own account, 5 in consignee own account).

Road occupancy: In the centre of Bordeaux, the time of road occupancy by delivery vehicles stopped in double parking is twice more than running delivery vehicles.

In order to compare the road occupancy of all the actors in the city (residents, firms, services, urban manager...), we propose as statistical unit the veh.km car unit (vehicle $\mathrm{km}$ in car unit). A light delivery commercial vehicle (van) is like 1.5 car, a truck (rigid) is 2 cars, an articulated lorry is 2.5 car. In this way, the components of urban goods transport are following:

- deliveries and pick-ups (total establishments) : $\quad 40 \%$

$\begin{array}{ll}\text { - purchasing trips (by car) : } & 50 \%\end{array}$

- urban management (building sites, networks maintenance, waste collection) : $10 \%$

According to the town, the share of urban goods traffic (UGT) in total traffic is: from $9 \%$ to $15 \%$ of trips, $13 \%$ to $20 \%$ of vehicles*km, $15 \%$ to $25 \%$ of vehicles*km (in car unit).

One of the main contributions of the surveys consisted in the knowledge of rules of urban management (the links between activities, operation mode, management mode, type of vehicles used, distance covered, number of served establishments, running time, parking place and parking time). Are directly linked with the type of activity, the number of deliveries and pickups, the operation structure, the management mode and the organisational mode.

The main relationships are between:

- Management mode and organisation mode (own account carries out mostly direct trip, third part transport uses rounds)

- type of vehicle and management mode (own account uses more light commercial vehicles, third part transport uses trucks)

- distances covered and management mode and organisation modes (the third part transport's round are more long than that of own account)

- distance covered between 2 stops and size of the round (more the round is long, more the distance between two stops is short)

- stop timing and size of the round (more the round has stops, more the delivery time is short).

A very important result is that the same relationships have been observed in the three surveyed towns: the comparison of the results of the three French freight transport surveys has shown a notable similarity in terms of diagnostic; the number of deliveries caused by each type of activity; and, inside each class of activity: the number of deliveries realised by type of vehicles; the share of the own account; the share of the different types of rounds. It is the proof that, for each class of activity, the overall economic and logistic structure is prevailing 
on the size and the geography of the towns. This result have permitted to transfer the knowledge issued from those surveys to others towns and to build a general model applicable for French and even European towns. In conclusion, the specificity and the contribution of the French establishment-driver surveys consists in :

- taking into account the exhaustiveness of urban goods transport,

- coupling methodology of survey and objectives (diagnosis, knowledge of demand, link between generation and development of flows, simulation of policy oriented scenarios).

- weighting which permits to calibrate the method for planning and modelling. (generation of deliveries and pickups, distance covered according to each activity sector, each management and organisational mode).

\section{Methods and technologies for data capture}

This last part consists of a critic examination of the various collection methods in order to try to ascertain which ones fit the relevance and the efficiency of the survey. Anyway, the objectives to describe the urban logistics in the global way need heavy surveys. Wermuth M. (2004) presents the different types of surveying methods and their advantages and disadvantages for business surveys : comparison between written (postal) interviews, personal (face to face) interviews, telephone interviews, internet interviews, traffic count using mobile phones. During the course of the surveys carried out in France, various interview procedures have been tested:

- in establishment surveys (face to face, with or without diary, CATI, phone-mail, internet...)

- in driver surveys, description of the routes and itineraries (by the drivers themselves, GPS, integration of a web-based survey with in-vehicle tracking, embarked surveys).

Those techniques of capture may be analysed according to the cost of the survey, the objectives, the coherence of the sources, the possibility of weighting of the data.

Regarding the quality of results, it appears that the establishment-driver survey method used in Bordeaux is better than the Marseilles and Dijon method:

According to the establishment surveys, face to face surveys are more efficient, because of the complexity of the questionnaire and the need for a diary on one week. It is nevertheless very expensive. The CATI method didn't allow a quick control of coherence (impossibility to link an answer with an another answer and to come back for modifying the answer). The questionnaire was too heavy and the CATI method was given up.

The embarked pollster (observer) method seems good, but it shows some drawbacks: the high cost and in that case, it is not possible to keep the link between the establishment visited by the driver and the route surveyed by the embarked pollster. It is very important to enforce the pollster training and the follow up in real time. 


\section{Aerial photography}

Aerial photographs have been sometimes used to give an instantaneous picture of the street occupancy by the vehicles in urban areas. A campaign of photographs was carried out above the city of Bordeaux (Routhier J.L, Araud C., 1997). By this mean, it has been possible to measure the number of cars, vans, rigid and articulated heavy vehicles who are parked or running on the road network and on the outdoors parking places: about $80 \%$ of the pavement was occupied by private cars. This work was costly, because the recognition and the counting of the vehicles was made manually. Picture via satellite are today sufficiently precise to distinguish the different outlines of vehicles. It could be a good solution for the measurement of the road occupancy of the different types of vehicles.

\section{The use of IT for survey assistance}

A lot of experiments and IT applications are available to make more attractive or more accessible the collection of specific data. We give some informations about two of them, internet surveys and GPS route capture.

A survey towards the consumers using internet for their purchase (e-commerce) can be approached via filling a "e-questionnaire". Thanks to an open on line survey management platform named LOGISKOP, several surveys have been carried out in various studies by the Laboratoire d'Economie des Transports. For example, a survey entitled "practices of food supplying of the e-consumer" was filled by 85 individuals. Another one entitled "e-commerce and mobility" were made easy with a very low cost, thanks to this platform. Among 1625 connections to the site, 1037 forms were totally filled.

The main advantages are the possibility to built dynamic questionnaires, which may be filled by any e-consumer and the answers may be immediately processed. The surveys may be open to the public or closed by a restriction by password. In the first case, it is possible to obtain answers effortlessly: the e-consumer from all around the world may reach the site and take part in the survey. However, Several brakes limit the use of this process: in the case of open share, the control of the honesty of the respondent is not possible; if there is a password control, it is not easy to find the e-mail address of the individual interested in answering the survey. This platform was developed in 2003 using PHP and Java Script languages. Several similar freeware tools are to day available (Alligier, 2007).

GPS is also a very attractive way of capturing the routes of the vehicles. It is easy and not very expensive to fit out a vehicle with a GPS transmitter. If the pulse frequency is around the second, the recording of the co-ordinates of the vehicle position becomes easy. This method may present nevertheless several drawbacks: the geo-location of the vehicle must be coupled with a interactive system where the driver or the on board pollster must add informations, like the nature of the stops (for example, GPS does not differentiate a stop caused by a traffic light and a stop for delivery), the description of the delivery, the characteristics of the 
establishment, etc. Interactive GPS device are expensive and need today a training who limits its use for GPS embarked surveys. Moreover, some artefacts in the capture (echo or loss of the signal) may involve a wrong route recording (Marchal, 2005).

\section{Conclusion of the review}

This review, obviously not exhaustive, brings out a great variety of methodological approaches of surveying urban goods transport. Current surveys are essentially vehicle surveys, focussed on the estimation of the vehicle performances in areas often wider than the towns (region, country). They make possible the assessment of commodity flows from a region to another. Generally, they are not built in order to analyse urban goods flows. Another class gathers the business surveys, whose main objective is to calculate the amount of the total business traffic (including passenger, goods, services etc). The corresponding questionnaires do not include thorough questions about goods movement at the local level.

In European countries in which urban freight data availability has been improved, it was either due to new national freight surveys or due to one-off projects and data collection efforts at an urban scale.

The surveys specifically oriented towards the urban goods vehicle flows assessment are seldom. The establishment-driver surveys developed in France, seem to be the most turned to the research of an exhaustive knowledge of the urban goods movement and to the assessment of the relationships between the logistic behaviour of the freight movement generators and the transport system.

\section{FROM DIAGNOSTIC TO SIMULATION TOWARDS DECISION MAKING}

Decisions makers need to know the flow generation sharing caused by each activity in order to understand and control the functioning of urban freight transport and its impact on the environment. That is the reason why they have to know the share of each activity (shippers: industry, handcraft, trade, wholesale, operators: hauliers, integrators, warehouses, own account and finally the households for their shopping) in the flow generation. As showed above in 2.6, establishment-driver surveys allow to realise such a diagnostic. We attempt to establish below the ability of such surveys to integrate the various policy measures to answer the main concerns of the stakeholders. 


\section{Indicators}

Common long distance transport indicators as tons, ton.km, energy intensity or empty running seem few relevant at the urban level. For example, energy intensity (Fuel consumed per tonkilometre) is relevant in the measurement of the impact of the freight transport between two regions. In order to carry goods inside the towns, the types of vehicles and frequencies are very much various and the unit of measurement depends on the type of vehicles used and it is very difficult to measure and to calculate without a totally disaggregated approach to the flows. The same goes for the empty running whose calculation needs the knowledge of the load graphs of each round carried out in the town. Nevertheless, following indicators have been recorded about the results of the establishment driver surveys.

\begin{tabular}{|c|c|c|}
\hline $\begin{array}{l}\text { Title and description of the } \\
\text { urban freight indicator }\end{array}$ & $\begin{array}{l}\text { Units in which the indicator } \\
\text { is measured }\end{array}$ & Purpose of the indicator \\
\hline $\begin{array}{l}\text { Ratio: Number of } \\
\text { Loading/unloading }\end{array}$ & $\begin{array}{l}\text { Number of deliveries and pick- } \\
\text { ups per week per employee in } \\
\text { each activity }\end{array}$ & $\begin{array}{l}\text { Make possible a fast appraisal of the } \\
\text { generation of deliveries and pick-ups in } \\
\text { a town without any survey. The } \\
\text { contribution of each industry sector is } \\
\text { calculable. }\end{array}$ \\
\hline Loading/unloading density & $\begin{array}{l}\text { Number of deliveries and pick- } \\
\text { ups per } \mathrm{km}^{2} \text { in a zone }\end{array}$ & $\begin{array}{l}\text { Measures the importance of the goods } \\
\text { flows in a zone }\end{array}$ \\
\hline $\begin{array}{l}\text { Loading/unloading intensity per } \\
\text { activity }\end{array}$ & $\begin{array}{l}\text { Number of deliveries and pick- } \\
\text { ups per activity in a zone }\end{array}$ & $\begin{array}{l}\text { Measures the contribution of each } \\
\text { industry sector to the goods flows }\end{array}$ \\
\hline Loading/unloading time & $\begin{array}{l}\text { Number of hours of on street } \\
\text { double parking for delivery or } \\
\text { pick-up in a zone, per vehicle, } \\
\text { per activity }\end{array}$ & $\begin{array}{l}\text { Measures the contribution of each } \\
\text { industry sector to the road congestion } \\
\text { by the on street double parking } \\
\text { deliveries }\end{array}$ \\
\hline $\begin{array}{l}\text { Distance covered for } \\
\text { Loading/unloading }\end{array}$ & $\begin{array}{l}\text { Number of kilometres covered } \\
\text { for one delivery or pick-up in a } \\
\text { zone, per vehicle, per activity }\end{array}$ & $\begin{array}{l}\text { Measures the contribution the running } \\
\text { vehicles delivering each industry sector } \\
\text { to the road congestion. }\end{array}$ \\
\hline $\begin{array}{l}\text { Average length of the first leg } \\
\text { from platform to the delivery area }\end{array}$ & $\mathrm{Km}$ & $\begin{array}{l}\text { Measure the impact of the location of } \\
\text { the platform delivering goods relating } \\
\text { to its market radius }\end{array}$ \\
\hline $\begin{array}{l}\text { Average distance travelled per } \\
\text { collection/delivery }\end{array}$ & $\begin{array}{l}\text { Kilometres per collection or } \\
\text { delivery }\end{array}$ & $\begin{array}{l}\text { Measure of the contribution of one } \\
\text { delivery/pick-up to the urban traffic } \\
\text { (per type of involved vehicle) }\end{array}$ \\
\hline $\begin{array}{l}\text { Total distance travelled on roads } \\
\text { in urban area by HGV, rigid } \\
\text { lorries, and LGV }(<3,5 \mathrm{~T}) \text { used. }\end{array}$ & $\begin{array}{l}\text { Total vehicle km per week in } \\
\text { urban areas }\end{array}$ & $\begin{array}{l}\text { Measure of the contribution of the total } \\
\text { industry activity on the traffic. }\end{array}$ \\
\hline $\begin{array}{l}\text { Average time taken per delivery } \\
\text { (per activity type, per vehicle, } \\
\text { own account, for hire...) }\end{array}$ & Minutes per delivery & $\begin{array}{l}\text { Measure of the time taken for } \\
\text { delivering in a tour, on a street, for an } \\
\text { industry activity,... }\end{array}$ \\
\hline
\end{tabular}




\begin{tabular}{|l|l|l|}
\hline $\begin{array}{l}\text { Title and description of the } \\
\text { urban freight indicator }\end{array}$ & $\begin{array}{l}\text { Units in which the indicator } \\
\text { is measured }\end{array}$ & Purpose of the indicator \\
\hline $\begin{array}{l}\text { Average speed per round } \\
\text { (including and excluding stops to } \\
\text { make deliveries) km/hour }\end{array}$ & Km per hour & $\begin{array}{l}\text { Measures the performance of the } \\
\text { rounds for each way of organisation, } \\
\text { type of vehicle. }\end{array}$ \\
\hline Average weight per kilometre & $\begin{array}{l}\text { Ton (or } \mathrm{kg} \text { ) } \mathrm{km} \text { per tour, per } \\
\text { activity, per type of vehicle }\end{array}$ & $\begin{array}{l}\text { Measures the performance of the } \\
\text { rounds for each way of organisation, } \\
\text { type of vehicle... }\end{array}$ \\
\hline $\begin{array}{l}\text { Greenhouse gas } \\
\text { and pollution according to the } \\
\text { zone, the vehicle, the activity, the } \\
\text { management }\end{array}$ & $\begin{array}{l}\text { - g Pollutant per km } \\
\text { - g CO2 per km }\end{array}$ & $\begin{array}{l}\text { Measure of the impact of urban goods } \\
\text { movement on the energy consumption, } \\
\text { local and global nuisance and } \\
\text { greenhouse gas. }\end{array}$ \\
\hline
\end{tabular}

Table 5: Urban freight transport indicators used in research projects in France

This table shows the wealth of the indicators which can be calculated by the way of the "establishment-driver" urban goods surveys. As shown in the third column, each indicator is useful to make a comprehensive diagnosis of the urban goods transport and helps to measure the involvement of the main components of the urban goods movement: industry activity types, ways of management (own account, third party), organisation (size of vehicle, size of the round). We show below that this approach is a very promising tool to improve completely the knowledge of the links between the activity and the goods transport at the urban scale, including the main components of sustainability (Segalou, Routhier et al. 2006).

\section{Modelling}

The comparison of the results of the three French freight transport surveys show a similarity of the results in terms of diagnostic. For example, the number of deliveries generated per employee in various activities is quite the same in the three towns. Other indicators are also quite similar: according to the activity distributed in 8 sectors, the share of the different size of vehicles (<3.5 tons, rigid heavy vehicles, articulated vehicles), the share of the own account and the third party, the different size of rounds. It is the proof that, in French urban areas, economy takes precedence over geography. It was consequently possible to link together into a model the main relationships between economy and transport system revealed by the surveys.

The policy oriented model Freturb has been developed (Routhier J.L. et al. 2001, Routhier J.L., Toilier F., 2007) on the basis of the establishment-driver surveys, which have been conceived and carried out in accordance with the structure of the model. On the basis of an establishment data register, and some zones geographical data, the model simulates the 
number of vehicle movements generated on each zone, the impact of the economic activity on road occupancy (traffic and also parking time) and several indicators for diagnostic, as time average for delivering goods for each size of vehicle. The recent development of this model is the calculation of the distribution of the flows in the urban area. It takes into account the round organisation of the vehicles routes. An environmental impact module is soon available. The main advantage of this model is that no localised specific survey is necessary for calibration. It needs only available data in all the French cities: establishment registers and geographical and network data (zoning, road network, speed average on links). A software, easy to implement is used by more than 25 French cities. It is possible to simulate the effects of several levers on urban logistics:

- outcome of the activity location (firms and households), its density, new regulations as time windows for delivering zones,

- new ways of supplying (home deliveries, e-commerce),

- urban logistics facilities and organisation (urban distribution centres, private-publicpartnership, spatial co-operative system,...).

\section{GENERAL CONCLUSION}

The pertinence of urban goods transport surveys lies in the capacity to give decision makers an account of the global urban freight transport functioning, ratios and data, in order to help them for decisions (town planning, regulation, prevision...). So, they have to take into account all components, own account and third party transport, all the goods exchanged between establishments, as well small as big firms, from light commercial vehicles to maxicode trucks. According to the latter requirement, we suggest several conditions of efficiency of urban goods surveys.

A stratified sample and a post stratification permit to improve noticeably the precision of coefficient of generation of deliveries and pick ups. The extension of the results is possible only if the size of sample is large. According to the precedent review, the association of business (establishments) surveys and vehicle travel diary survey (drivers) have been carried out in several cases. It seems to be a very effective approach, in order to answer the following issues:

- to allow a unbiased sample expansion;

- to explain the transport conditions by the establishment logistics functioning and to feed a policy oriented model;

- to put road occupation in touch with parked or running vehicles (impact on congestion, tool of management for decision maker). 
In that case:

1. In our opinion, the most relevant observation unit is the movement (delivery and pickup).

2. Picking a sample in a reliable and comprehensive register of establishments, containing at least his address, his detailed good activity code the and number of employees.

3. The choice of the town is linked to the involvement of local authorities (urban community, Chamber of commerce and industry). A support from government department responsible for road maintenance and issuing building permits can be useful (as in the case of Bordeaux). Their help is useful for knowledge of the specificity of the city and also technical, for helping surveys management.

4. The choice of consulting for the execution of survey is very important. Transparency, total collaboration is necessary. The quality of results depends of the possibility to react quickly, face to a problem. Moreover, the consulting have to be well up on research approach rather than marketing approach.

5. Collection method: face to face is the more efficient technique, but expensive. In order to reduce the cost, new methods can be investigated, as the Internet survey. It consists in filling questionnaire on Internet, with a direct control by the researcher.

6. The cost of such a survey is high. The financing has to be well estimated (to take the unforeseen). Unlike the household travel surveys, urban goods surveys are one-off surveys. It appears difficult to carry out such surveys in a periodic way, due to their high cost and the lack of involvement of the stakeholders and funding authorities.

7. Recruiting pollsters (observers) is fundamental. These surveys are heavy and complex. The pollster have to be adaptable, reactive, and have to understand the stakes. A good training and tests are necessary

8. The representativeness depends on a good stratification.

Several constraints must be taken into account:

The heaviness of survey administration does not permit to include comprehensive joint business trips. The cost is high and has to be assumed by local and national partnership. Several collection methods may be carried out for the same sample, according to the size and the activity of the establishments, according the transport operator or the size of the round for the drivers interviews.

As an extension, it would be useful to combine trade establishment surveys with customer of shops surveys. That permits to measure the relation between stores supplying and the household purchasing behaviour. A tool for modelling interaction between business traffic and individual traffic should be very useful.

We noted that methodological papers about surveys are rare. They have never been put forward enough in the field of world research. The references they cite are generally limited 
to national papers, in their national language (for example in France or Germany). Few of them cite international researches. That limits the scattering in the scientific community and among persons in charge of carrying out surveys.

Fortunately, the context is changing quickly, as the TRB special session, initiatives in European programs (BESTUFS II WP3, INTERREG), show it. These initiatives could permit to create links between different researchers of different countries and with communities planners We hope that this paper will permit to contribute to a better transferability of experiences carried all over the world in order to direct the survey technical choices regarding the targeted objectives.

The thoughts and the methodological propositions formulated in the previous conferences, and those made clear in this paper, could permit to lay the foundations for a more mature methodological debate. The remarks of Meyburg and Mbwana (2002) are patent: "It is generally observed that data collection, storage, and distribution are expensive activities, and they urged data users to make full use of available data. Any effort to collect new freight data should be preceded by an understanding as to why the new data are needed"

It may allow to draw the main orientations to harmonise survey methods, like for passenger household surveys, and at last to allow the comparability of results obtained in different countries.

\section{REFERENCES}

Alligier L. (2007) Mesurer l'impact du commerce électronique sur la logistique urbaine, $\mathrm{PhD}$ Thesis on Transport Economics, LET, Université de Lyon, 234 p.

Beaudoux E., (2006) Exploitation de l'Enquête ECHO sur le transport de marchandises en ville, Master Thesis, Paris-Dauphine University.

Bonnafous A. (2000) Les marchandises en ville: le problème méthodologique de l'appréhension statistique, pp ; 85-92, in L’intégration des marchandises en ville dans le système des déplacements urbains, LET Entretiens Jacques Cartier proceedings, Montreal.

Browne M., Allen J., (2006) D 3.1 Best practice in data collection, modelling approaches and application fields for urban transport models I. Theme: Urban freight data collection - synthesis report, Best urban Freight Solutions II - EU-FP6 Co-ordination Action, $119 \mathrm{p}$.

Browne M., Allen J. and Christodoulou, Patier D., Routhier J.L., Ambrosini C., (2007), Comparison of urban freight data collection in European countries, $11^{\text {th }}$ WCTR Berkeley.

Gentile G. and Vigo D., (2007), Movement generation and trip distribution for freight demand modelling applied to city logistics, working paper. 
Dufour J.G., (1995), Exploitation de l'enquête “Chargeurs “ de l’INRETS, en termes de marchandises en ville, CETUR.

Hunt J.D., Stefan K.J., Broownlee A.T. (2005), An establishment(based Survey of Urban Commercial Vehicle Movements in Alberta: Survey Design, Implementation and Results, TRB annual meeting CD-Rom.

Iding M., Meester W.J., Tavasszy L.A (2002), Freight trip generation by firms, $42^{\text {nd }}$ Europan congress of the Regional Science Association, Dortmund.

Needs to be further up list if alphabetical Canadian Council 1999 National Roadside Study Project report (2001).

Krüger D. 2004, Planning process for urban goods movement, (iTrans consulting), 2004 annual conference of the Transport Association of Canada, Quebec city, Quebec.

Garrido R.A., (2001) Insights on freight and commercial vehicle data needs, ITSC Costa Rica conference proceedings, Elsevier.

IAURIF, 2004 Le transport de marchandises par VUL en Ile de France, 190 p.

Patier D., Routhier J.L., Ambrosini C., Durand S., Bossin P., Gelas P., Le Nir M., (1997), Transport de marchandises en ville : Enquête quantitative réalisée à Bordeaux, final report MELT-DRAST, LET, 230 p. + annexes.

LET, (2000), Transport de marchandises en ville : Enquêtes quantitatives réalisées à Dijon et Marseille, 2 final reports MELT-DRAST, LET, 2x120 p.

Marchal F., Hackney J. and Axhausen K.W. (2005), Efficient map-matching of large GPS data sets - Tests on a speed monitoring experiment in Zurich. Transportation Research Record 1935, 93-100.

OECD (2003) Delivering the Goods: $21^{\text {st }}$ Century Challenges to Urban Goods Transport, OECD. http://www.oecdbookshop.org/oecd/display.asp?TAG=X8OWU8XX4X7X9945977HWN\&CID=\&L ANG=EN\&SF1=DI\&ST1=5LMQCR2K2N5H

Patier, Cholez, Routhier, Ambrosini (2004) Transport de marchandises en ville quelles spécificités, quelles méthodes - volet 3 : Méthodologie des enquêtes tournées dans les agglomérations urbaines, Rapport pour la DRAST-MELT, LET, 36 p.

Patier D., Routhier J.L., (1998) Transport de marchandises en ville : une méthodologie d'enquêtes quantitatives adaptée, RTS.

Rizet C., Guilbault M. et al. (2004), tracking along the transport chain with the shipper survey, ITSC Costa Rica conference proceedings, Elsevier.

Routhier J.L., Segalou E., Durand S. (2001), Mesurer l'impact du transport de marchandises en ville - Le modèle de simulation FRETURB, Guide technique MELT, ADEME, LET, 104 p.

Routhier J.L., Toilier F. (2007), FRETURB V3, a policy oriented software tool for modelling urban goods movement, $11^{\text {th }}$ WCTR, Berkeley. 
Routhier J.L, Araud C., 1997, Tentative de modélisation du transport de marchandises en ville - Exploitation des photos aériennes à Bordeaux, rapport pour la DRAST-MELTT.

Segalou E., Routhier J.L. (LET), Albergel A. (Aria Tehcnology), De Rham C. (System Consult),. (2006) Méthodologie pour un bilan environnemental physique du transport de marchandises en ville, ADEME ed. Connaître pour agir, 88 p.

TRB (2003) A Concept for a National Freight Data Program Committee on Freight Transportation Data: A Framework for Development, Transportation Research Board Special Report 276, Washington, D.C.

Wermuth M., Neef C., Steinmeyer I., (2004) Goods and Business Traffic in Germany, ITSC Costa Rica conference proceedings, Elsevier.

WSP and Katalysis (2002) Report B4 - Review of Data Sources, Review of Freight Modelling, report produced as part of Review of Freight Modelling project with University of Westminster, University of Leeds, Rand Europe, MDS-Transmodal, Oxford Systematics, Parsons Brinckerhoff and Imperial College. http://www.dft.gov.uk/stellent/groups/dft_econappr/documents/page/dft_econappr_5 07986.pdf

\section{Internet sites}

http://www.bestufs.net

http://www.citylogistics.org

http://www.COST355.Inrets.fr

http://www.interreg-medocc.info

http://www.docapolis.com 
$388^{\text {th }}$ International conference on Survey Methods in Transport

Table of contents

How to Improve the Capture of Urban Goods Movement Data? ........................................... 1

Why urban goods movement surveys today?................................................................ 1

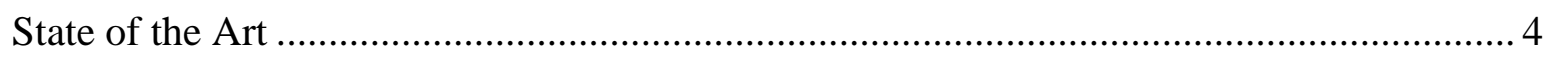



Urban freight oriented projects confronted with data collection issues ............................ 5

Bestufs II : a recent survey on urban goods data collection......................................... 6

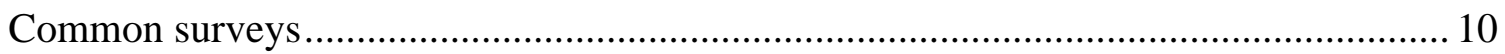

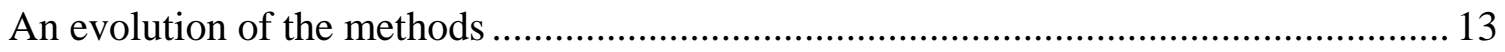

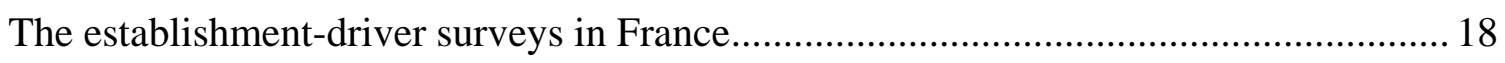

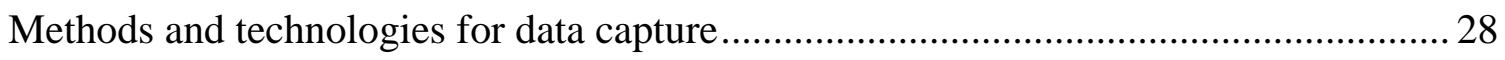

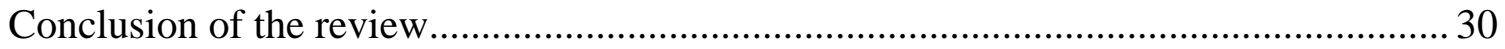

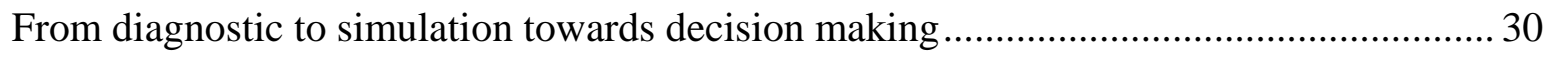

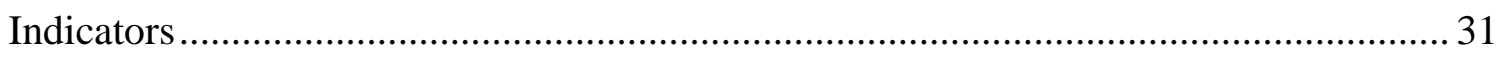

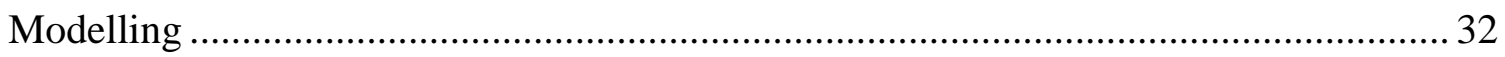

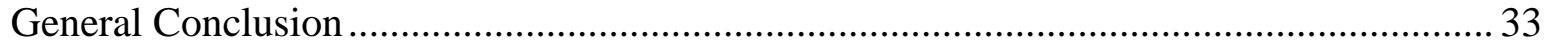

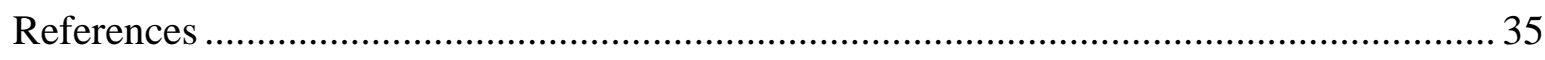

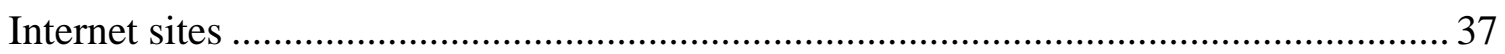

